\title{
The Relationship Between Working Capital Management And Firm's Profitability: An Empirical Investigation For An Emerging Asian Country
}

Melita Charitou, University of Nicosia, Cyprus

Petros Lois, University of Nicosia, Cyprus

Halim Budi Santoso, University of Nicosia, Cyprus

\begin{abstract}
The major objective of this study is to examine the relationship between working capital management and firm's profitability. Using a dataset of all Indonesian firms over the period 19982010, results show that the Cash Conversion Cycle and Net Trade Cycle are positively associated with the firm's profitability. Results also show that firm's riskiness, as measured by the debt ratio, is negatively related to the firm's Return on Assets. The results of this study should be of interest to executives and major stakeholders, such as investors, creditors, and financial analysts, especially after the recent global financial crisis and the latest collapses of giant organizations worldwide.
\end{abstract}

Keywords: Capital Markets; Working Capital Management; Empirical Investigation; Asia

\section{INTRODUCTION}

$\mathrm{n}$ the midst of the current global financial crisis, where several collapses of giant firms took place, such as General Motors, Lehman Brothers, and Kodak, executives are trying to determine the major determinants of this financial turmoil. There are, though, both external (less controllable) and internal (more controllable) factors to be taken into consideration. Regarding the latter, researchers and practitioners brought to the forefront of the international capital markets research the importance of management of organizational resources and especially working capital management. Working capital is described as the capital available to meet the day-to-day operations and, depending on the industry, it could be a relatively high percentage of the total assets of the organization. Efficient utilization of firm's resources, as it relates to working capital management, means that executives should find effective and efficient ways to deal with the cash available for the day-to-day operations in order to achieve the optimum impact. On the one hand, excessive working capital will limit the firm's cash and, on the other hand, an inadequate level of working capital will lead to reduced profits since a number of clients will switch to a competitor. Indeed, executives have been emphasizing the efficient utilization of a firm's resources since there is a belief that it has an effect on the firm's financial performance; however, there has been little empirical evidence on this specific issue (Ricci and N. DiVito, 1998; Garcia-Teruel and Martinez Sonano, 2007; Hill et al., 2010; Charitou et al, 2010).

In this study, we empirically investigate the effect of working capital management on a firm's financial performance in an emerging market. We hypothesize that working capital management leads to improved financial performance and especially to increased profitability. Our data set consists of all firms listed on the Indonesian stock exchange over the 13-year period 1998-2010. Using multivariate regression analysis, our results indicate that the Cash Conversion Cycle and Net Trade Cycle are associated with the firm's profitability. 


\section{LITERATURE REVIEW AND MOTIVATION FOR THE STUDY}

Thus far, various researchers examined the effect of working capital management to the company's profitability with mixed and inconclusive results. Shin and Soenen (1998) analyzed the relationship between Net Trade Cycle and company profitability over the period 1975-1995. Results showed that there is a strong negative relationship between the amounts of the firm's working capital with company profitability, leading to the conclusion that high levels of working capital are detrimental to the firm's profitability. This finding was also supported by Deloof (2003) for large Belgian non-financial firms. Deloof's results also suggest that reduction in the number of days in accounts receivable and days in inventory leads to increases in the firm's profitability. Beaumont, Smith and Begemann (1997), using Cash Conversion Cycle as a proxy for working capital management, found that current liabilities divided by funds flow have a great relationship with return on investment. Moreover, Lazaridis and Tryfonidis (2006), using a dataset of firms listed in the Athens Stock Exchange, showed that managers could create value for shareholders by correctly handling the Cash Conversion Cycle and by keeping each different component to an optimum level. In an emerging European market, Charitou et.al (2010), using a dataset of firms listed in the Cyprus Stock Exchange, showed that there is negative association between the firm's profitability and days in inventory, Cash Conversion Cycle, days sales outstanding, and creditor payment period. These researchers suggested that efficient utilization of the firm's resources leads to increased profitability and to the reduction of the firm's volatility of profits. This efficiency, according to these authors, is expected to lead to the reduction in default risk and to the improvement of the firm's value.

As it can be seen from the aforementioned empirical evidence, there are inconclusive and inconsistent results with regard to the role of working capital management on a firm's financial performance. There also exist differences in the measurement of the working capital management. Some researchers used Net Trade Cycle (Shin and Soenen, 1998; Beaumont Smith and Begemann, 1997; Erasmus, 2010) and other researchers used Cash Conversion Cycle (Deloof, 2003; Charitou, et. al, 2010; Garcia-Teruel and Martinez-Solano, 2007). Unlike Cash Conversion Cycle, Net Trade Cycle is calculated by expressing working capital as a percentage of sales, thus controlling firm size. Consequently, the value of a firm's Net Trade Cycle indicates the number of days' sales that the firm has to finance its net working capital investment.

We extend prior studies in the following respects.

1. First, we examine both the cash operating cycle as well as Net Trade Cycle.

2. Second, we use a relatively large time period to investigate this issue - a 13-year period.

3. Third, we extend prior research by examining an emerging Asian country; namely, Indonesia.

4. Fourth, we perform an industry analysis as well as alayze the largest industries in Indonesia - Food and Beverages, Tobacco, Consumer Goods, Retail and Wholesale, and Apparel and Others.

To the best of our knowledge, no one has examined this issue using data from Indonesia or other emerging Asian countries. It is important to examine this issue for Indonesia since their stock exchange is considered one of the most successful in Asia. The relatively good performance of that index may be driven by the good working capital management of the listed firms, among other factors, thus attracting more investors. The results of this study may lead executives to pay more attention to working capital management and subsequently lead to the shareholders' value creation. We expect that if executives of Indonesian firms pay more attention to the efficient utilization of resources - working capital management - these firms may have a stronger and smoother stream of earnings which may lead to value creation and, at the same time, to smoother changes in stock prices, thus mitigating the large volatility in stock prices.

\section{RESEARCH METHODOLOGY}

\section{Dataset}

Our dataset consists of all firms listed in the Indonesian Stock Exchange over the period 1998-2010. The financial statements used for this study were retrieved from ECFIN Summary Report and Indonesia Stock Exchange. ECFIN is a research, publishing, and consulting institution in the field of economics and finance since 
1989. Every year, ECFIN publishes a summary of financial statements in cooperation with Indonesia Stock Exchange. We used firms from the following industrial sectors: Food and Beverages, Tobacco, Consumer Goods, Retail and Wholesale, and Apparel and Others. The reasons why this research focuses on these sub-sectors are:

1. First, these sub-sectors are considered to be the biggest in Indonesia. For example, in 2010 Indonesia received income from cigarette tax - Rp 55.9 trillion (equal to US\$ 6.536 billion, 1 US\$ $=$ Rp 8.552) ${ }^{1}$.

2. Second, Pawley (2006) mentioned that focusing on industrial firms is of great importance where a relatively large investment in working capital is typically required in order to support the activities of a firm.

The selection of these industrial sectors is also consistent with Erasmus (2010), who examined the same industrial sector for the Johannesburg Securities Exchange during the period 1989-2007.

\section{Empirical Models}

In order to test the relationship between a firm's profitability and working capital management, we use the following regression models for each variable measured on an annual basis:

$\mathrm{ROA}_{\mathrm{i}}=\beta_{0}+\beta_{1} \mathrm{CCC}_{\mathrm{i}}+\beta_{2} \mathrm{SIZE}_{\mathrm{i}}+\beta_{3} \mathrm{SG}_{\mathrm{i}}+\beta_{4} \mathrm{CR}_{\mathrm{i}}+\beta_{5} \mathrm{DR}_{\mathrm{i}}+\mathrm{e}_{\mathrm{i}}$

$\mathrm{ROA}_{\mathrm{i}}=\beta_{0}+\beta_{1} \mathrm{NTC}_{\mathrm{i}}+\beta_{2} \mathrm{SIZE}_{\mathrm{i}}+\beta_{3} \mathrm{SG}_{\mathrm{i}}+\beta_{4} \mathrm{CR}_{\mathrm{i}}+\beta_{5} \mathrm{DR}_{\mathrm{i}}+\mathrm{e}_{\mathrm{i}}$

where

ROA - Return on Assets for every company

CCC - Cash Conversion Cycle for every company

SIZE - Size of the firm which is represented by the natural logarithm of total assets

$\mathrm{SG}$ - Sales growth for every firm

CR - Current Ratio for every firm

DR - Debt Ratio for every firm

e - Error Term

\section{Measurement of Variables}

The dependent variable used to quantify profitability in this study is the Return on Assets (ROA), calculated as the operating profit before taxes divided by total assets. Return on Assets is a profitability ratio which shows the effectiveness of the company to manage its assets in order to generate revenue. In this article, Return on Assets (ROA) is defined as follows:

$$
R O A=\frac{\text { NetSales }}{\text { TotalAssets }}
$$

Our independent variables are: 1) Stockholding Period, 2) Debtors Collection Period, 3) Creditors Collection Period, 4) Natural Logarithm of Total Assets, 5) Current Ratio, 6) Sales Growth, 7) Debt Ratio, 8) Cash Conversion Cycle, and 9) Net Trade Cycle.

Cash Conversion Cycle measures how long a firm will get cash if it increases its investment in resources in order to expand customer sales. Cash Conversion Cycle (CCC) is defined as follows:

\footnotetext{
${ }^{1}$ Source : www.okezone.com. News is available in http://economy.okezone.com/read/2010/02/17/20/304413/cukai-rokok-naikpendapatan-pemerintah-tetap
}

(C) 2012 The Clute Institute http://www.cluteinstitute.com/ 
Cash Conversion Cycle $(\mathrm{CCC})=$ Inventory Collection Period (ICP) + Trade Receivables Collection Period (RCP) - Trade Payable Collection Period (PCP).

where

$I C P=\frac{\text { Inventory }}{\text { CostOfSales }} * 365$

$R C P=\frac{\text { Trade } \operatorname{Re} \text { ceivables }}{\text { NetSales }} * 365$

PCP $=\frac{\text { TradePayables }}{\text { CostOfSales }} * 365$

Another measurement of working capital management is Net Trade Cycle (NTC). Beaumont, Smith and Begemann (1997) used this working capital management measure to examine the effect of working capital on Return on Investment for South African industrial firms. In this research, Net Trade Cycle is used in order to find the differences between Net Trade Cycle and Cash Conversion Cycle to measure the relationship between working capital management and profitability. Net Trade Cycle is defined as follow:

$$
N T C=\frac{\text { Trade } \operatorname{Re} \text { ceivables }+ \text { Inventories }- \text { TradePayable }}{\text { NetSales }} * 365
$$

Additional independent variables used are: firm size (SIZE); Sales Growth (SG), Current Ratio (CR), and Debt Ratio (DR). Those variables are defined as follows:

SIZE $=\operatorname{Ln}($ TotalAssets $)$

$S G=\frac{\left(\text { NetSales }_{i}-\text { NetSales }_{i-1}\right)}{\text { NetSales }_{i-1}}$

$C R=\frac{\text { CurrentAssets }}{\text { CurrentLiabilities }}$

$D R=\frac{\text { TotalLiabilities }}{\text { TotalAssets }}$

\section{EMPIRICAL FINDINGS}

Table 1 presents descriptive statistics for all firms (total of 718 firm-year observations) over the 13-year period 1998-2010. Results show that the average of a firm's total assets is US \$212.802 million with the total net sales US $\$ 283.791$ million. Average trade receivables are US $\$ 18.452$ million (8.67\% of the total assets) and average inventory is US $\$ 59.104$ million (27.77\% of the total assets). Results also show that the ROA for Indonesian firms is 6.4\%. This figure is less than the average ROA of the listed firms in South Africa (Erasmus, 2010), but it is slightly higher than the average ROA of the firms listed in the Cyprus Stock Exchange (Charitou et.al., 2010). 
Table 1: Descriptive Statistics

In this table we present descriptive statistics for all our firms listed in the Indonesian Stock Exchange over the period 1998-2010.

\begin{tabular}{|l|c|c|c|c|c|}
\hline & $\mathbf{N}$ & Minimum & Maximum & Mean & Std. Deviation \\
\hline Return on Assets & 718 & -1.8 & 0.6 & 0.1 & 0.2 \\
\hline Total Asset & 718 & 0.1 & 5232.0 & 212.8 & 487.2 \\
\hline Trade Receivable & 718 & 0.0 & 278.6 & 18.5 & 37.8 \\
\hline Inventories & 718 & 0.0 & 2232.6 & 59.1 & 193.8 \\
\hline Total Liabilities & 718 & 0.0 & 2634.4 & 119.2 & 262.2 \\
\hline Net Sales & 718 & 0.0 & 4801.0 & 283.8 & 612.7 \\
\hline Cost of Good Sold & 718 & 0.0 & 3400.4 & 213.4 & 452.4 \\
\hline Stockholding Period & 718 & 0.0 & 1146.3 & 88.7 & 89.3 \\
\hline Receivables Collection Period & 718 & 0.0 & 965.1 & 45.6 & 61.8 \\
\hline Payable Collection Period & 718 & 0.0 & 1581.1 & 49.2 & 74.0 \\
\hline Cash Conversion Cycle & 718 & -144.7 & 1143.4 & 85.0 & 131.0 \\
\hline Net Trade Cycle & 718 & -91.4 & 3849.2 & 77.7 & 170.4 \\
\hline Sales Growth & 718 & -1.0 & 22303.7 & 34.3 & 834.3 \\
\hline Debt Ratio & 718 & 0.0 & 163.2 & 1.0 & 6.7 \\
\hline Size of Company & 718 & -2.3 & 8.6 & 4.2 & \\
\hline Current Ratio & 718 & 0.0 & 557.6 & 5.6 & \\
\hline
\end{tabular}

Results also show that there is a difference between the average of Net Trade Cycle and Cash Conversion Cycle. The average of Net Trade Cycle is 77.7 days, while the average of Cash Conversion Cycle is 85.0 days. The movement of stockholding period, trade receivable, and trade payable during the observation year is shown in Graph 1. On the other hand, in Graph 2 we present the movement of Cash Conversion Cycle, Net Trade Cycle, and Return on Assets. From Graph 2, we observe that the average Return on Assets was going down until the year 2004 and then started to go up right after 2004. On the other hand, the Cash Conversion Cycle remains steady. When the Cash Conversion Cycle went up in years 2005 and 2006, the Return on Assets was increasing. These descriptive results indicate that there is a relationship between Return on Assets and Cash Conversion Cycle. In contrast, Net Trade Cycle has been too volatile during the recent global financial crisis, especially during the year 2008 when the global crisis started.

\section{Trend of Stockholding Period, Trade Receivable, and Trade Payable (1998 - 2010)}

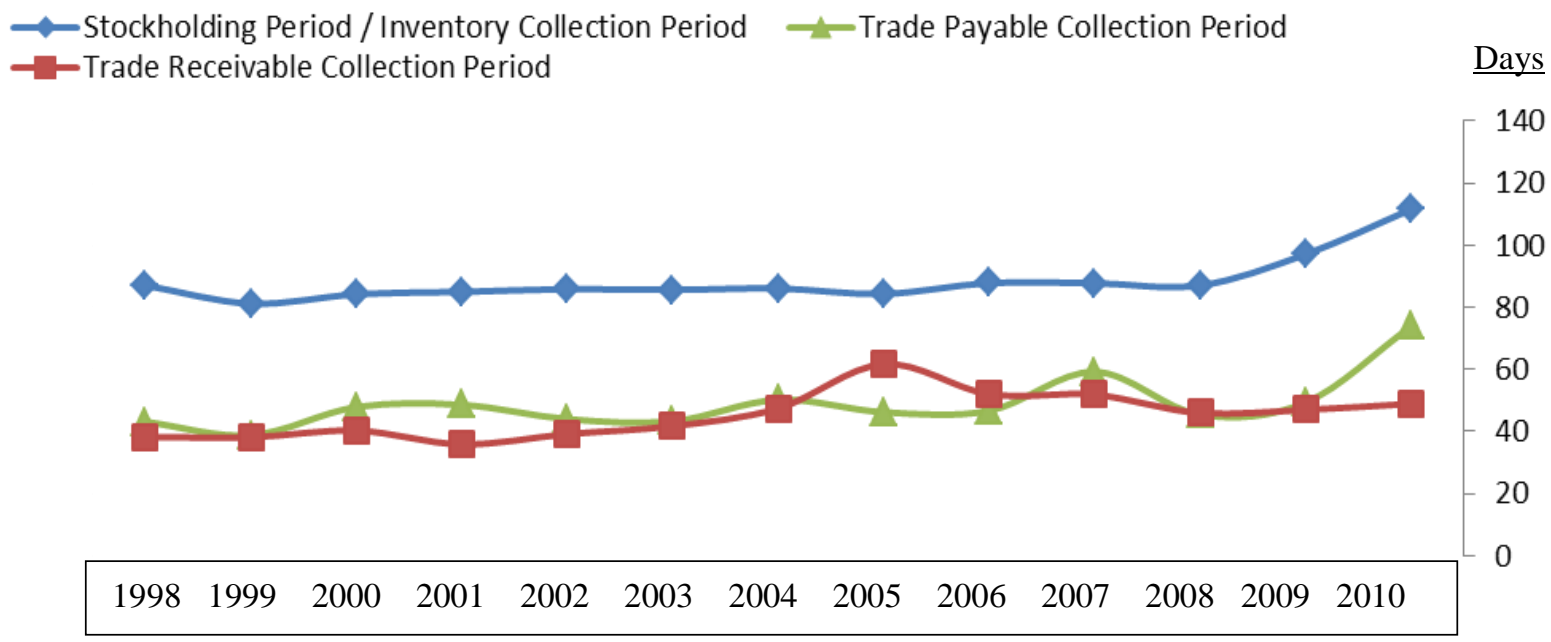

Graph1 


\section{Trend of Cash Conversion Cycle and Net Trade Cycle (1998 - 2010)}

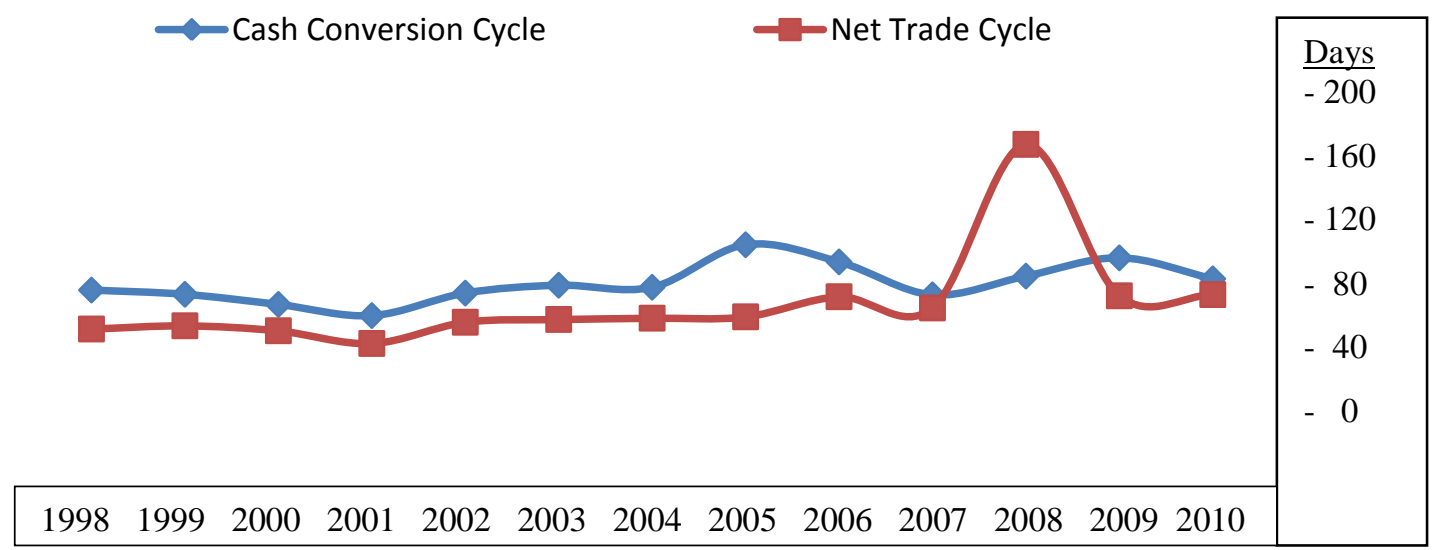

Graph 2

Results in Table 2 represent Pearson's correlation analysis. Results show that Return on Assets is positively related with the Cash Conversion Cycle and firm size. These results indicate that greater Cash Conversion Cycles lead to greater Return on Assets. On the contrary, Debt Ratio has an inverse relationship with the Return on Assets, indicating that the firm's profitability is inversely related to its riskiness. Moreover, results presented in this table indicate that there is no multicollinearity among the independent variables. The maximum Variance Inflation Factor (VIF) is less than 3.5 since $\mathrm{VIF}=1 /\left(1-\mathrm{R}^{2}\right)$. Econometricians state that collinearity problems exist if VIFs are more than 5 .

Table 2: Pearson Correlation Analysis

In this table, we present Pearson correlation analysis statistics

for all our firms listed in the Indonesian Stock Exchange over the period 1998-2010.

\begin{tabular}{|c|l|c|c|c|c|c|c|c|}
\hline & & ROA & CCC & NTCycle & Size & Growth & CR & Debt ratio \\
\hline 1 & Return on Assets (ROA) & 1.00 & $.169^{* *}$ & 0.07 & $.404 * *$ & 0.02 & -0.02 & $-.376^{* *}$ \\
\hline & & & 0.00 & 0.06 & 0.00 & 0.56 & 0.58 & 0.00 \\
\hline 2 & Cash Conversion Cycle (CCC) & & 1.00 & $.517 * *$ & 0.07 & 0.01 & 0.01 & -0.05 \\
\hline & & & & 0.00 & 0.07 & 0.73 & 0.85 & 0.16 \\
\hline 3 & Net Trade Cycle (NTC) & & & 1.00 & 0.03 & 0.01 & 0.02 & -0.04 \\
\hline & & & & & 0.48 & 0.89 & 0.60 & 0.34 \\
\hline 4 & Size & & & & 1.00 & 0.03 & 0.01 & -0.22 \\
\hline & & & & & & 0.51 & 0.76 & 0.00 \\
\hline 5 & Sales Growth & & & & & 1.00 & -0.01 & 0.00 \\
\hline & & & & & & & 0.90 & 0.99 \\
\hline 6 & Current Ratio (CR) & & & & & & & \\
\hline & & & & & & & & -0.01 \\
\hline 7 & Debt Ratio & & & & & & 0.77 \\
\hline
\end{tabular}

** Correlation is significant at the 0.01 level (2-tailed)

In order to test the relationship between profitability and working capital management, we run multiple regression analyses for our Models 1 and 2. In both models, we use Return on Assets (ROA) as a dependent variable. In Model 1, we used Cash Conversion Cycle and three additional variables - firm's size, riskiness as measured by the debt ratio, and firm's growth - as independent variables. In Model 2, we use Net Trade Cycle instead of using Cash Conversion Cycle and the rest of the variables are the same. Results for Models 1 and 2 are presented in Panels A and B in Table 3, respectively. Results in Panel A show that the model is statistically 
significant with an $\mathrm{R}^{2}$ of $26.8 \%$, indicating the firm's profitability. Consistent with the Pearson correlation results presented earlier, Cash Conversion Cycle and firm size are positively related to a firm's profitability. The positive association between Cash Conversion Cycle and firm size indicate that larger firms with greater levels of inventory and better credit terms from clients lead to greater profitability and thus to increased firm value. In Table 1, we also observe that the average stockholding period/inventory collection period is relatively high compared to the average receivable collection period and average payable collection period. Results also show that the debt ratio has an inverse relationship with the firm's profitability. These results indicate that higher riskiness is an impediment to the firm's profitability. This is due to the fact that higher debt levels increase interest expense as well as the probability of default. As far as the Net Trade Cycle is concerned, results in Panel B of Table 3 show that there is a positive association between Net Trade Cycle and Return on Assets. Results regarding firm size and the debt ratio remain the same as those presented in Panel A of Table 3. This model is also significant, as indicated by the F-statistics and the $\mathrm{R}^{2}(0.254)$.

Table 3: Multivariate Regression Analysis

In this table, we present multivariate regression analysis results for all our firms listed in the Indonesian Stock Exchange over the period 1998-2010. Definition of variables: ROA = yearly Return on Assets for every company; CCC = Cash Conversion Cycle for every company; SIZE = size of the firm which is represented by natural logarithm of total assets, calculated yearly; SG = sales growth for every firm; $\mathrm{CR}=$ current ratio for every firm; $\mathrm{DR}=$ debt ratio for every firm; e = error Term.

$*, * *, * * *$ : statistically significant at $1 \%, 5 \%$, and $10 \%$, respectively.

Panel A: Model 1

$\mathrm{ROA}_{\mathrm{i}}=\beta_{0}+\beta_{1} \mathrm{CCC}_{\mathrm{i}}+\beta_{2} \mathrm{SIZE}_{\mathrm{i}}+\beta_{3} \mathrm{SG}_{\mathrm{i}}+\beta_{4} \mathrm{CR}_{\mathrm{i}}+\beta_{5} \mathrm{DR}_{\mathrm{i}}+\mathrm{e}_{\mathrm{i}}$

(Eq. 1)

\begin{tabular}{lccc} 
& Coefficient & t-value & Significance \\
\hline Constant & $-0.108^{* * *}$ & -6.008 & 0 \\
Cash Conversion Cycle & $0.131 * * *$ & 4.073 & 0 \\
Sales Growth & 0.012 & 0.36 & 0.719 \\
Debt Ratio & $-0.298^{* * *}$ & -9.06 & 0 \\
Size & $0.33 * * *$ & 10.045 & 0 \\
Current Ratio & -0.028 & -0.888 & 0.375 \\
\hline
\end{tabular}

Model's $\mathrm{R}^{2}=26.8 \%$

Panel B: Model 2

$\mathrm{ROA}_{\mathrm{i}}=\beta_{0}+\beta_{1} \mathrm{NTC}_{\mathrm{i}}+\beta_{2} \mathrm{SIZE}_{\mathrm{i}}+\beta_{3} \mathrm{SG}_{\mathrm{i}}+\beta_{4} \mathrm{CR}_{\mathrm{i}}+\beta_{5} \mathrm{DR}_{\mathrm{i}}+\mathrm{e}_{\mathrm{i}}$

\begin{tabular}{ccc} 
Coefficient & t-value & Significance \\
\hline$-0.1 * * *$ & -5.525 & 0 \\
0.051 & 1.588 & 0.113 \\
0.013 & 0.396 & 0.693 \\
$-0.301 * * *$ & -9.081 & 0 \\
$0.337 * * *$ & 10.162 & 0 \\
-0.029 & -0.886 & 0.376 \\
\hline
\end{tabular}

(Constant)

Net Trade Cycle

Sales Growth

Debt Ratio

Size

Current Ratio

Model's $\mathrm{R}^{2}=25.4 \%$

\section{CONCLUSIONS}

The on-going global financial crisis brought to the forefront (of the international capital markets research) the efficient utilization of firms' resources since there is evidence that better utilization of firms' resources leads to shareholder value creation. Our dataset consists of 728 firm-year observations of firms listed in the Indonesian Stock Exchange over the period 1998-2010 for the following industries: Food and Beverages, Tobacco, Consumer Goods, Wholesales, and Apparel and Others. Using multivariate regression analysis, our results indicate the following:

1. There exists a positive association between working capital management and a firm's profitability.

2. There exists an inverse relationship between a firm's riskiness and profitability. 
Implications from the above results are:

1. First, firms should pay attention to working capital management. It seems that taking advantage of credit terms to the suppliers is valued positively by the market. Moreover, especially during turbulent times, firms should be able to handle, in the best possible way, both their inventories and receivables.

2. Firms need to maintain inventories at certain levels in order to satisfy clients and thus avoid losing them.

3. As far as credit terms with clients is concerned, firms should be competitive in the sense that they have to provide such credit terms in order to keep their clients and attract new ones as well.

In the on-going global economic crisis, the results of this study should be of great interest to executives and major stakeholders since efficient utilization of a firm's working capital leads to increased profitability and thus to value creation.

\section{AUTHOR INFORMATION}

Dr. Melita Charitou is an Associate Professor of Finance and Accounting, University of Nicosia, Cyprus. Dr Charitou has a Ph.d in Finance and Accounting from Middlesex University, UK. She has published in refereed international journals in Finance, Economics and Accounting. Her research areas of interest are capital markets research, corporate finance, corporate governance, investments, and international financial analysis. Address for correspondence: Division of Finance and Economics, School of Business, University of Nicosia, Cyprus. E-mail: charitou.m@unic.ac.cy. Corresponding author.

Dr. Petros Lois is an Associate Professor of Accounting. He is the holder of the PricewaterhouseCoopers' Chair in Business Research and the Head of the Accounting Department, University of Nicosia, Cyprus. His research areas of interest are capital markets research, working capital management, shipping and international financial analysis. He has published in refereed international journals in Accounting, Finance, Management and Shipping. Address for correspondence: Division of Accounting, School of Business, University of Nicosia, Cyprus. E-mail: Lois.p@unic.ac.cy

Halim Budi Santoso holds an MBA from the University of Nicosia, Cyprus. His research area of interest is capital markets research, working capital management and international financial analysis. Address for correspondence: Division of Accounting, School of Business, University of Nicosia, Cyprus.

\section{REFERENCES}

1. Bhunia, A., Khan, I., Mukhuti, S. (2011), “A Study of Managing Liquidity”, Journal of Management Research, Vol. 3, No. 2

2. Charitou, M, M. Elfani, and Lois, P. (2010), "The Effect of Working Capital Management on Firm's Profitability: Empirical Evidence From An Emerging Market”, Journal of Business \& Economics Research, Volume 8, Number 12.

3. Deloof, M. (2003), "Does Working Capital Management Affect Profitability of Belgian Firms?", Journal of Business, Finance, and Accounting, Vol. 30, No. 3 \& 4, pp. 164 - 177

4. $\quad$ Erasmus, P. D. (2010), "Working Capital Management and Profitability: The Relationship between the Net Trade Cycle and Return on Assets", Management Dynamics, Vol. 19, No. 1

5. $\quad$ Erasmus, Pierre (2010), "The Relationship Between Working Capital Management and Profitability for South African Listed Industrial Firms", The Business Review, Cambridge, Vol. 15, Num. 1

6. Garcia-Teruel, Pedro Juan, Solano, Pedro Martinez (2007). "Effects of Working Capital Management on SME Profitability", International Journal of Managerial Finance, Vol. 3 No. 2 pp. 164 - 177.

7. Lazaridis, I. and Tryfonidis, D. (2006), "The Relationship between Working Capital Management and Profitability of Listed Companies in the Athens Stock Exchange, Journal of Financial Management and Analysis, Vol. 19, No. 1, pp. 26 - 35

8. Mohamad, N. E. A., Sahad, M. N. (2010), "Working Capital Management: The Effect of Market Valuation and Profitability in Malaysia", International Journal of Business and Management, Vol. 5, No. 11, pp. 140 $-147$ 
9. Nazir, M. S., Afza, T. (2009), 'Impact of Aggressive Working Capital Management Policy on Firms' Profitability". The IUP Journal of Applied Finance, Vol. 15, No. 8, pp. 19 - 30

10. Pandey, S., Jaiswal, V. K. (2011), "Effectiveness on Profitability: Working Capital Management", SCMS Journal of Indian Management, January - March, pp. 73 - 80.

11. Raheman, A., Nasr, M. (2007), "Working Capital Management and Profitability - Case of Pakistani Firms", International Review of Business Research Papers, Vol. 3, March, pp. 279 - 300

12. Raheman, A., Qayyum, A., Afza, T., Bodla, M. A. (2010), "Sector Wise Analysis of Working Capital Management and Firm Performance in Manufacturing Sector in Pakistan", Interdisciplinary Journal of Contemporary Research in Business, Vol. 2, No. 7, pp. 412 - 437

13. Shin, H. H. and Soenen, L. (1998), "Efficiency of Working Capital Management and Corporate Profitability", Financial Practise and Education, Vol. 8, pp. 37 - 45

14. Sur, Debasish., Chakraborty, Kaushik (2011), "Evaluating Relationship of Working Capital and Profitability: A Study of Select Multinational Companies in the Indian Pharmateutical Sector", The IUP Journal of Management Research, Vol. X, No. 2 
NOTES 